\title{
The Effects of Rearing Temperature on American Glass Eels
}

\author{
Carrie J. Blakeslee ${ }^{1}{ }^{*}$, Heather S. Galbraith ${ }^{1}$, Robert M. Deems ${ }^{1,2}$ \\ ${ }^{1}$ US Geological Survey, Leetown Science Center, Northern Appalachian Research Laboratory, Wellsboro, PA, USA \\ ${ }^{2}$ US Army Corps of Engineers, Regulatory Branch, Philadelphia, PA, USA \\ Email: *cblakeslee@usgs.gov
}

How to cite this paper: Blakeslee, C.J., Galbraith, H.S. and Deems, R.M. (2018) The Effects of Rearing Temperature on American Glass Eels. Agricultural Sciences, 9, 1070-1084.

https://doi.org/10.4236/as.2018.98074

Received: July 9, 2018

Accepted: August 28, 2018

Published: August 31, 2018

Copyright $\odot 2018$ by authors and Scientific Research Publishing Inc. This work is licensed under the Creative Commons Attribution International License (CC BY 4.0).

http://creativecommons.org/licenses/by/4.0/

(c) (i) Open Access

\begin{abstract}
American eels are declining throughout their range requiring a better understanding of physiological requirements of all life stages and optimal conditions for laboratory rearing and aquaculture. American glass eels (Anguilla rostrata) were housed for 3 weeks at $14^{\circ} \mathrm{C}, 18^{\circ} \mathrm{C}, 22^{\circ} \mathrm{C}$, or $26^{\circ} \mathrm{C}$ to determine optimal juvenile rearing temperature in the laboratory. All treatments exhibited weight gain over the course of the study except the $14^{\circ} \mathrm{C}$ treatment; however, there were only marginal differences in final weight between the $18^{\circ} \mathrm{C}$ and $14^{\circ} \mathrm{C}$ treatments and no differences in length. Variation in length and weight generally increased as temperature increased with significant differences in the standard error of weight between $14^{\circ} \mathrm{C}$ and the $22^{\circ} \mathrm{C}$ and $26^{\circ} \mathrm{C}$ treatments and between $18^{\circ} \mathrm{C}$ and $26^{\circ} \mathrm{C}$. Mortality was significantly greater than expected by chance at $26^{\circ} \mathrm{C}(7$ deaths) and no mortality was observed at $14^{\circ} \mathrm{C}$. Body condition (based on the residuals from the weight-length relationships), conversely, was lowest in the $14^{\circ} \mathrm{C}$ treatment. Considering all response variables, optimal laboratory rearing conditions were observed between $18^{\circ} \mathrm{C}-22^{\circ} \mathrm{C}$. Within a week of experimentation, evidence of gas bubble disease was observed and by completion noted in all treatments except at $14^{\circ} \mathrm{C}$, likely as a function of decreased gas solubility at warmer temperatures. Levels of total gas pressure $(103 \%-108 \%)$ and $\Delta \mathrm{p}(28-54 \mathrm{~mm} \mathrm{Hg})$ values may account for the gas bubbles observed.
\end{abstract}

\section{Keywords}

Eel Culture, Gas Bubble Disease, Juvenile Eels

\section{Introduction}

Catadromous fish populations are declining globally and the American eel (Anguilla rostrata) is no exception [1] [2]. Declines in eel populations have been 
linked to water contaminants, harvest pressure, disease, and migration passage obstruction [1] [3] [4] [5] [6]. Historically, eels have comprised a major proportion of the total fish biomass within some systems [7] [8] [9]. For example, in the 1960 s the American eel comprised 37\% of the total weight and $20 \%$ of the abundance of fish species within the Flatbrook River system (NJ), a tributary to the Delaware River [9]. Juvenile eels serve as a food source for water fowl and larger fish such as pikes, trout, and bowfins, while adult eels prey on macroinvertebrates, crustaceans, bivalves and fishes [9] [10] [11] [12] [13]. Recent research also suggests that the American eel serves as the primary host fish for successful reproduction of the freshwater mussel, Elliptio complanata, in parts of its range [14]. The impact of a continued decline of eel populations will amplify negatively on the river ecosystems it historically inhabited.

The eel, like most catadromous fish, has a complex life cycle that begins with spawning in the Sargasso Sea. Migratory leptocephalus larvae drift in ocean currents until reaching coastal waters anywhere between Greenland and northern South America [15]. There they metamorphose into transparent, sexually undifferentiated glass eels and can remain in estuarine waters for as long as a year before migrating upstream into freshwater as pigmented elvers [16]. Further maturation to the yellow eel phase occurs in freshwater, during which sexual differentiation of the gonads occurs [17], a process that can take between 7 and 25 years to complete [18]. Once mature and ready to spawn, yellow eels assume a metallic body coloration (silver eel phase) and adapt both morphologically and physiologically for their migration back to the Sargasso Sea [19] [20].

Sustaining current American eel populations and restoring historical populations via eel stocking and relocation programs are priorities in both the United States and Canada [3] [21]. The ability to rear all stages of American eels in captivity is a key research need for successful large-scale stocking or aquaculture programs. Studies on rearing both American and European (Anguilla anguilla) eels have analyzed the effects of diets [19] [22] [23], water chemistry [24] [25], chemical cues [26], and culture system design [27] [28] [29] on juvenile survival and growth rate.

As with most fish, water temperature is a key component in eel culture because optimal temperatures promote the greatest growth, body condition, and survival. Studies on European eels have shown optimum rearing temperatures between $22^{\circ} \mathrm{C}-25^{\circ} \mathrm{C}$ [19] [24] [30]. However, optimum rearing temperatures have also been shown to differ within this species depending on eel body size such that smaller eels required warmer temperatures for maximum growth [30]. Optimal temperature for American eel elvers collected in Central America was reported even higher, between $28^{\circ} \mathrm{C}-29^{\circ} \mathrm{C}$ [31]. However, few studies report optimal growing conditions for earlier stages of eel development (glass eel and leptocephali) and in populations at northern latitudes. Further studies are needed to fully understand temperature effects on eels and, as eel culture continues to grow, identifying optimum rearing conditions for juvenile stages is es- 
sential. The purpose of this study was to expand our understanding of the American eel and enhance juvenile glass eel culture by studying the effects of 4 temperature treatments on the survival and growth of glass stage American eels.

\section{Materials and Methods}

\subsection{Experimental Specimens}

American glass eels were collected in April, 2011 by Maryland Department of Natural Resources and US Fish and Wildlife Service from Turville Creek (Ocean City, MD) and transported to the US Geological Survey Northern Appalachian Research Laboratory in Wellsboro, PA. Once at the laboratory, a subset of eels were weighed and measured and divided by the total number of eels to get an estimate of weight/individual. Mean $( \pm$ SE) eel length was $55.84( \pm 0.77) \mathrm{mm}$ and mean $( \pm$ SE) weight was $0.12( \pm 0.03)$ g. Approximately 13,000 glass stage American eels were initially housed in $371 \mathrm{~L}$ fiberglass tanks set at $20^{\circ} \mathrm{C}$ with an exchange rate of approximately $18 \mathrm{~L} \cdot \mathrm{min}^{-1}$. Within 24 hours of arrival to the laboratory, eels were treated for parasites with a 1 hour standing bath of $250 \mathrm{ppm}$ formalin solution. The holding tank received a 50:50 mixture of dry commercial mash and chicken liver (described below), fed daily (4\% of tank eel weight). Once the population appeared generally parasite-free (4 days after arrival), a subset of glass eels, still transparent in color, were removed from the holding tank and placed into experimental conditions.

\subsection{Experimental Procedure}

Four temperature treatments were investigated in this study $\left(14^{\circ} \mathrm{C}, 18^{\circ} \mathrm{C}, 22^{\circ} \mathrm{C}\right.$, or $26^{\circ} \mathrm{C}$ ) and each temperature treatment consisted of a single head box feeding 5 replicate eel housing units. Each housing unit consisted of 2 nested $20.8 \mathrm{~L}$ polyethylene buckets: an inner eel holding bucket and an outer reservoir bucket. A section on the bottom of each holding bucket $\left(90.25 \mathrm{~cm}^{2}\right)$ was perforated with holes $(0.25 \mathrm{~cm}$ diameter) and covered with $750 \mu \mathrm{m}$ mesh to prevent eels from escaping through the perforated holes. This holding bucket was suspended within a solid reservoir bucket to create a flow-through system with a water depth of approximately $11.5 \mathrm{~cm}$. Water was fed into the top of each holding bucket from a centralized head box with $0.64 \mathrm{~cm}$ diameter latex tubing at a rate of $10 \mathrm{~mL} \cdot \mathrm{sec}^{-1}$. After passing through an outdoor degassing tower, well-water is pumped into the NARL facility and either flows directly to experimental set-ups at well-temperature (between $8^{\circ} \mathrm{C}-11^{\circ} \mathrm{C}$ ) or flows through a boiler loop to be heated and is then fed to experimental set-ups. Water in our treatment buckets was a mixture of well-water and heated well-water except in the $26^{\circ} \mathrm{C}$ treatment which was solely heated well-water. Water was mixed in a single headbox for each treatment and distributed to the individual replicate buckets.

Head boxes were randomly assigned 1 of the 4 temperature treatments. Twenty-five eels were randomly selected (from the population of 13,000), collectively weighed, and placed in each bucket. Individual eels were not weighed or 
measured initially to avoid handling stress prior to experimentation. Eels were placed in their respective housing units at an initial water temperature of $20.2^{\circ} \mathrm{C}$ $\pm 0.04^{\circ} \mathrm{C}$. Water temperature was gradually increased or decreased by $2^{\circ} \mathrm{C}-3^{\circ} \mathrm{C}$ per day until final treatment temperatures were reached. Final treatment temperatures were maintained for an additional 21 days, after which the experiment was concluded.

Eels were fed in excess of cessation (based on data from Degani and Gallagher (1995) and personal observations) daily $0.5 \mathrm{~g}$ ( $\sim 17 \%$ of eel weight) of a dry-food mixture and $1 \mathrm{~g}$ of a mash-chicken liver mixture. Over-feeding the eels ensured that enough food would be supplied regardless of temperature treatment to avoid any interactions between food and temperature. Dry food was composed of brine shrimp flakes (Hatchery flakes, Zeigler Bros, Inc.), freeze-dried Cyclops-eeze (Liquid Life Argent Cyclop-Eeze Whole Freeze-Dried), and starter mash (Bio Vita Starter and Fry Mash, Crumble; Bio-Oregon, Inc.) at a ratio of 1 g brine shrimp: $3 \mathrm{~g}$ Cyclops-Eeze: $100 \mathrm{~g}$ mash. As a supplement, typically 4 hours after the dry food was administered, a mixture of puréed chicken liver and starter mash (equal parts by weight) was added to each bucket.

All housing buckets and their mesh were also cleaned daily; reservoir buckets were emptied and scrubbed once a week. After 6 days of exposure to experimental temperatures, gas bubbles were observed on some of the eels. Presence of eels with gas bubbles was recorded for the remainder of the experiment in addition to weekly gas measurements of total dissolved gas, percent saturation of oxygen and nitrogen, and $\Delta \mathrm{p}$ (pressure difference between the total gas pressure and barometric pressure). Following 21 days of experimental temperature exposure, eels were removed, anesthetized using MS-222 at 45 ppm, individually weighed (after gently removing excess and dripping water from the nets containing the eels), and their lengths were measured. Final gas measurements were also made and water samples were collected to determine final ammonia concentrations using standard phenate methods [32].

\subsection{Statistical Analysis}

A weight-length relationship was developed for all eels using the log form of the allometric growth equation $W=a L^{b}$ where $W$ is total wet weight in $g, L$ is total length in $\mathrm{cm}$, and $a$ and $b$ are constants describing the relationship between weight and length [33]. Because the slope parameter $b$ was $>3$, Fulton's K was not used to assess body condition for comparison among treatments [33] [34]. Instead, residuals from the model were tested for normality and homogeneity of variance and compared among temperature treatments using ANOVA.

Since mortality varied among buckets and treatments, eel mass was compared on a mass/eel basis. Because we did not measure individual eel weights at the start of the experiment, initial individual eel mass was calculated by dividing the entire mass of each housing unit by the total number of eels $(n=25)$ per bucket. Data on eel mass, length, and condition were natural log transformed prior to all 
analyses to meet statistical assumptions. Two-way analysis of variance (ANOVA) and Tukey's post hoc test were used to compare the net effects of treatment (temperature) and time (initial vs. final) on ln transformed eel wet weight. One-way ANOVA followed by Tukey's post hoc test were used to compare final individual mass and length among treatments, standard error (used as an estimation of variation in body size) of mass and length between treatments, and differences in condition between temperature treatments.

Chi-square analysis was used to determine if frequency of mortality and gas bubbles differed from expected frequencies (due to chance). Finally, ANOVA with Tukey's post hoc test were used to determine if the $\Delta \mathrm{p}$, percent total gas pressure, percent oxygen saturation, and percent nitrogen saturation differed among treatments. Due to unequal variances among treatments, a non-parametric Kruskal-Wallis test was used to evaluate differences among treatments in final ammonia concentrations. In several instances, ammonia concentrations were below the detection limits of our methods and resulted in a slightly negative ammonia concentration; in these cases, ammonia concentrations were assumed to be zero for statistical analyses.

\section{Results}

Final eel wet weight was significantly greater than initial wet weight $\left(\mathrm{F}_{1,32}=5.44\right.$, $\mathrm{p}<0.05)$, with a marginal difference between treatments $\left(\mathrm{F}_{3,32}=2.41, \mathrm{p}<0.09\right)$ and no interaction between time and treatment $\left(\mathrm{F}_{3,32}=1.68, \mathrm{p}=0.190\right)$ (Figure 1(a)). In particular, there was a marginal difference between the $18^{\circ} \mathrm{C}$ and $14^{\circ} \mathrm{C}$ treatments, such that eels weighed more at $18^{\circ} \mathrm{C}$ than $14^{\circ} \mathrm{C}$. Change in eel mass (mean final mass/eel-initial bucket mass/total number of eels) was greatest for the $22^{\circ} \mathrm{C}$ treatment $(+0.012 \mathrm{~g})$ and only decreased in the $14^{\circ} \mathrm{C}$ treatment $(-0.003 \mathrm{~g})$, but these changes in eel mass did not significantly differ among treatments $\left(\mathrm{F}_{3,16}=1.90, \mathrm{p}=0.171\right)$ (Figure $\left.1(\mathrm{~b})\right)$.

Final eel length varied between 46 and $69 \mathrm{~mm}$ (average $=57 \mathrm{~mm}$ ) and wet weight between 0.039 and $0.348 \mathrm{~g}$ (average $=0.143$ ) (Table 1$)$. Both values were greatest in the $18^{\circ} \mathrm{C}$ treatment, however final length $\left(\mathrm{F}_{3,16}=1.04, \mathrm{p}=0.401\right)$ and weight $\left(\mathrm{F}_{3,16}=2.34, \mathrm{p}=0.112\right)$ did not differ significantly between treatments. The variation (i.e. standard error within a bucket) in final eel length also did not differ significantly between treatments $\left(\mathrm{F}_{3,16}=2.18, \mathrm{p}=0.130\right)$; however, variation in eel wet weight (as measured in the standard error around the means) was significantly greater in the $22^{\circ} \mathrm{C}$ and $26^{\circ} \mathrm{C}$ treatments compared to $14^{\circ} \mathrm{C}$ treatment $\left(\mathrm{F}_{3,16}=7.65, \mathrm{p}<0.05\right)$ and significantly greater in the $26^{\circ} \mathrm{C}$ than in the $18^{\circ} \mathrm{C}\left(\mathrm{F}_{3,16}=7.65, \mathrm{p}<0.05\right)$ (Table $1 \&$ Figure 2$)$. The slope $(\mathrm{b})$ in the relationship between $\log W$ and $\log L$ increased with increasing temperature $\left(14^{\circ} \mathrm{C}, 3.6\right.$; $18^{\circ} \mathrm{C}, 3.8 ; 22^{\circ} \mathrm{C}, 4.3$; and $26^{\circ} \mathrm{C}, 4.8$; Figure 3 ); however, there were no significant differences among treatments in the residuals from the modeled weight-length relationship $\left(\mathrm{F}_{3,16}=0.427, \mathrm{p}=0.737\right)$. 

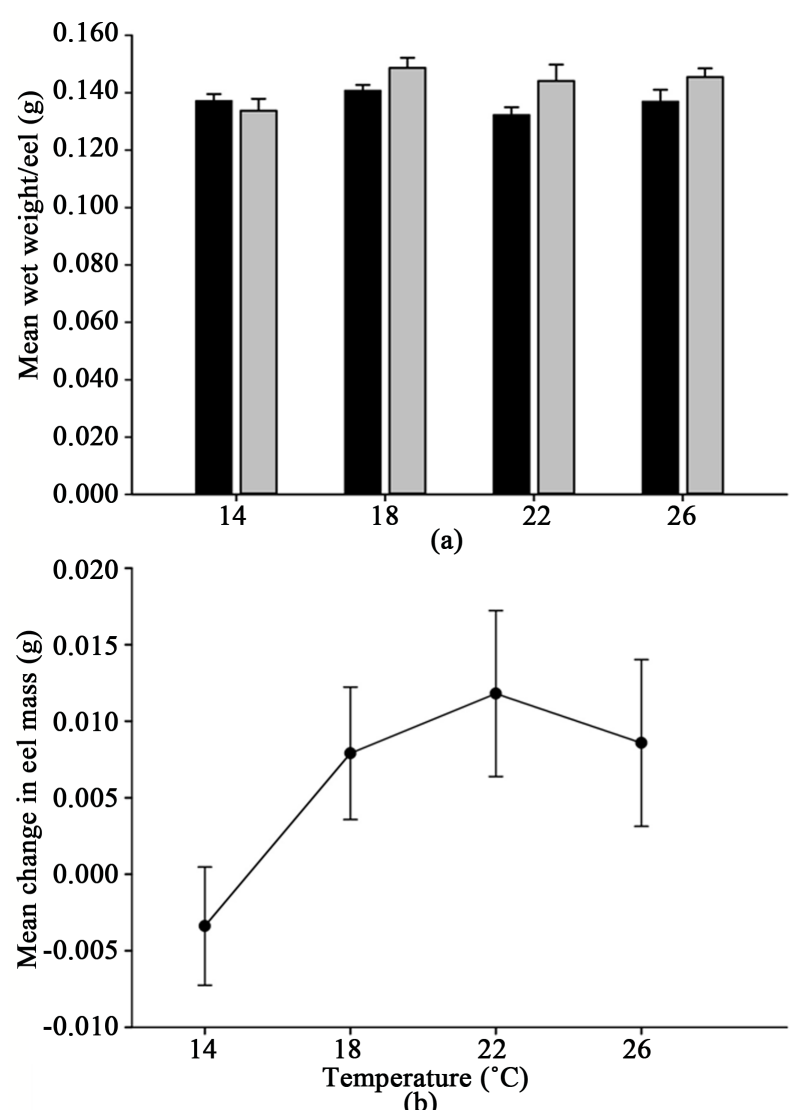

(b)

Figure 1. Initial (black bar) and final (gray bar) mean $( \pm \mathrm{SE})$ eel weight (calculated as mass of all eels in a bucket/total number of eels) (a) and average change in eel mass (calculated as (final bucket mass/total number of eels) —(initial bucket mass/total number of eels)) (b) for each temperature treatment. There was a significant difference between initial and final eel weight $\left(\mathrm{F}_{1,32}=5.44, \mathrm{p}<0.05\right)$, a marginal difference in eel weight $\left(\mathrm{F}_{3,32}=\right.$ $2.41, \mathrm{p}<0.09)$ between the 18 and $14^{\circ} \mathrm{C}$ treatment, and no interaction between time and treatment $\left(\mathrm{F}_{3,32}=1.68, \mathrm{p}=0.190\right)$ (a) and there was no significant difference between treatments in the mean change in eel mass $\left(\mathrm{F}_{3,16}=1.90, \mathrm{p}=0.171\right)(\mathrm{b})$.

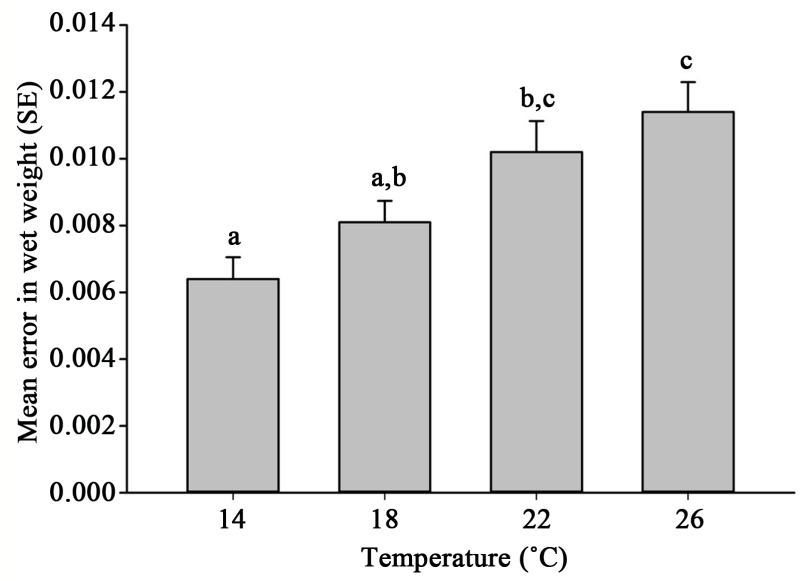

Figure 2. Mean standard error of eel wet weight in $n=5$ replicate buckets for each of 4 temperature treatments. Different letters indicate significant differences among temperature treatments at $\alpha=0.05$. Error bars represent the standard error of the means. 


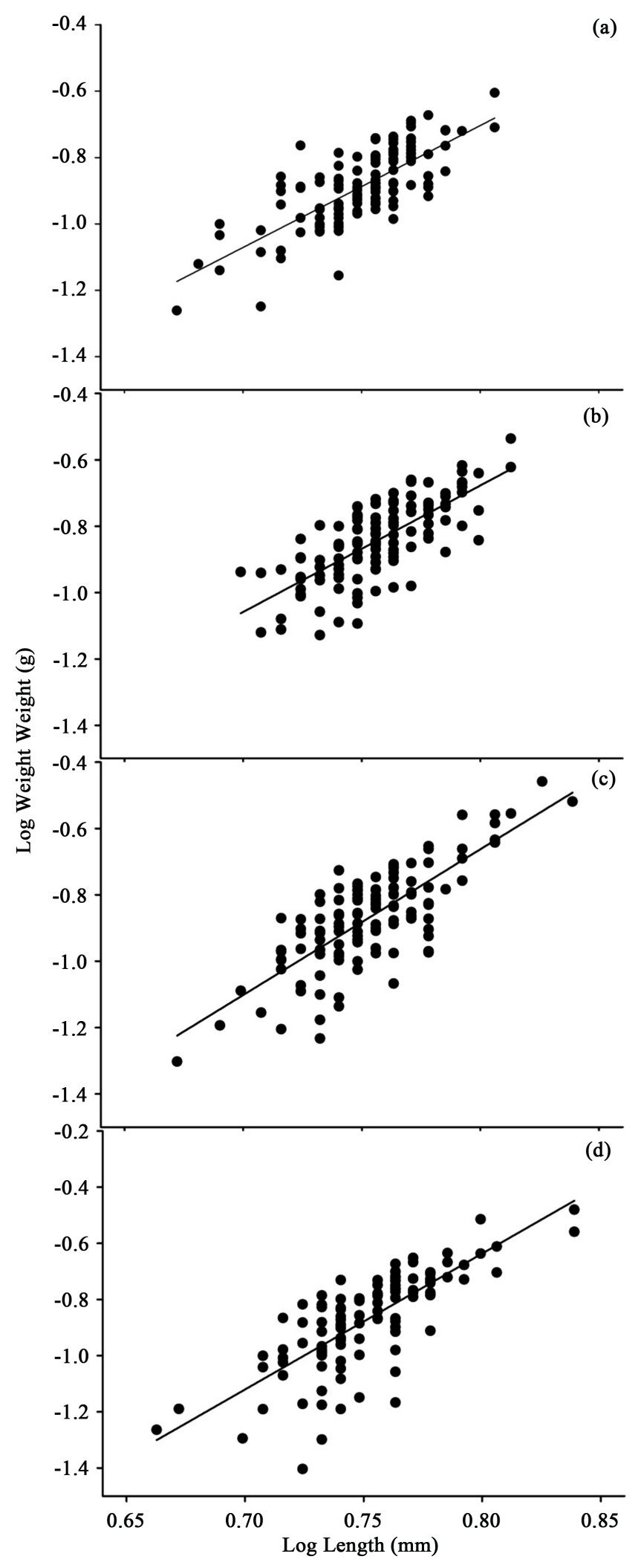

Figure 3. The relationship between log length $(\mathrm{mm})$ and $\log$ wet weight $(\mathrm{g})$ for each of 4 temperature treatments. Corresponding slope (b) values for each treatment were $3.6((\mathrm{a})$ $\left.14^{\circ} \mathrm{C}\right), 3.8\left((\mathrm{~b}) 18^{\circ} \mathrm{C}\right), 4.3\left((\mathrm{c}) 22^{\circ} \mathrm{C}\right)$, and $4.8\left((\mathrm{~d}) 26^{\circ} \mathrm{C}\right)$. 
Table 1. Mean ( \pm SE) and range for water temperature (Temp), final length (Length), final weight (Weight), slope (b) describing the relationship between the logs of weight and length, difference in total dissolved gas pressure relative to barometric pressure $(\Delta \mathrm{p})$, total gas pressure (TGP), oxygen saturation, nitrogen saturation, and ammonia concentration; number of buckets with gas bubbles observed (Gas Obs); and total mortality (number of individual eels) observed for the 4 temperature treatments (Treat). Mean (SE) represent $n=5$ replicates per treatment for temperature, length, weight, body condition, and ammonia. Mean (SE) for dissolved gas measurements represent headbox measurements at $n=3$ time points.

\begin{tabular}{|c|c|c|c|c|c|c|c|c|c|c|c|c|}
\hline Treat & & $\operatorname{Temp}\left({ }^{\circ} \mathrm{C}\right)$ & $\begin{array}{l}\text { Length } \\
(\mathrm{mm})\end{array}$ & Weight (g) & $\begin{array}{l}\text { Slope } \\
\text { (b) }\end{array}$ & $\begin{array}{c}\Delta \mathrm{p} \\
(\mathrm{mm} \cdot \mathrm{Hg})\end{array}$ & TGP (\%) & $\mathrm{O}_{2}$ Sat $(\%)$ & $\mathrm{N}_{2}$ Sat (\%) & $\begin{array}{l}\text { Ammonia } \\
\left(\mathrm{mg} \cdot \mathrm{L}^{-1}\right)\end{array}$ & $\begin{array}{c}\text { Gas Obs } \\
(\mathrm{N})\end{array}$ & $\begin{array}{c}\text { Mortality } \\
(\mathrm{N})\end{array}$ \\
\hline \multirow[t]{2}{*}{14} & Mean (SE) & $14.2(0.01)$ & $56(0.5)$ & $0.134(0.004)$ & 3.6 & $32(4)$ & $104.8(0.5)$ & $137.6(5.3)$ & $96.3(1.3)$ & $0.016(0.004)$ & 0 & 0 \\
\hline & Range & $13.7-14.8$ & $47-64$ & $0.055-0.248$ & & $28-40$ & $103.8-105.5$ & $131.8-148.2$ & $93.9-98.5$ & $0.008-0.028$ & & \\
\hline \multirow[t]{2}{*}{18} & Mean (SE) & $18.0(0.01)$ & $57(0.4)$ & $0.149(0.004)$ & 3.8 & $40(5)$ & $105.9(0.3)$ & $141.9(6.3)$ & $96.6(2.0)$ & $0.009(0.006)$ & 2 & 4 \\
\hline & Range & $17.6-18.3$ & $50-65$ & $0.074-0.291$ & & $31-48$ & $105.6-106.6$ & $134.4-154.5$ & $92.8-99.5$ & $0.000-0.029$ & & \\
\hline \multirow[t]{2}{*}{22} & Mean (SE) & $22.5(0.04)$ & $57(0.2)$ & $0.144(0.006)$ & 4.3 & $45(8)$ & $106.7(0.6)$ & $146.1(3.1)$ & $96.5(1.5)$ & $0.000(0.000)$ & 4 & 1 \\
\hline & Range & $21.6-23.4$ & $47-69$ & $0.050-0.348$ & & $30-55$ & $105.5-107.6$ & $140.6-151.3$ & $93.5-98.4$ & $0.000-0.000$ & & \\
\hline \multirow[t]{2}{*}{26} & Mean (SE) & $25.4(0.01)$ & $57(0.3)$ & $0.146(0.003)$ & 4.8 & $46(7)$ & $106.8(0.5)$ & $152.5(6.0)$ & $95.0(2.1)$ & $0.004(0.002)$ & 5 & 7 \\
\hline & Range & $24.2-25.9$ & $46-69$ & $0.039-0.331$ & & $33-54$ & $105.9-107.5$ & $143.9-164.0$ & $90.7-97.5$ & $0.000-0.011$ & & \\
\hline
\end{tabular}

A total of 11 buckets contained eels with gas bubbles (Table 1). The majority of these observations ( 9 out of 11 ) were made in the $22^{\circ} \mathrm{C}$ and $26^{\circ} \mathrm{C}$ treatments, however distribution of gas bubble buckets among treatments was not different from chance $\left(\mathrm{X}_{(3)}^{2}=5.36, \mathrm{p}=0.147\right)$. Observations of mortality, however, differed significantly from chance $\left(\mathrm{X}_{(3)}^{2}=10, \mathrm{p}<0.02\right)$. The greatest mortality was observed in the $26^{\circ} \mathrm{C}$ treatment ( 7 individuals) followed by the $18^{\circ} \mathrm{C}$ treatment (4 individuals); little to no mortality was observed in the $14^{\circ} \mathrm{C}$ and $22^{\circ} \mathrm{C}$ treatments (Table 1).

Mean nitrogen saturation varied between $95.0 \%$ and $96.6 \%$ while mean oxygen saturation varied between $137.6 \%$ and $152.5 \%$ (Table 1). Both percent nitrogen $\left(\mathrm{F}_{3,8}=0.18, \mathrm{p}=0.905\right)$ and oxygen $\left(\mathrm{F}_{3,8}=1.41, \mathrm{p}=0.308\right)$ saturation did not differ significantly between treatments. There was a marginal difference in total gas pressure between treatments $\left(\mathrm{F}_{3,8}=3.31, \mathrm{p}<0.08\right)$, where total gas pressure generally increased with increasing temperatures (Table 1 ). $\Delta \mathrm{p}$ ranged between 28 and 55, however there was no significant difference among treatments $\left(\mathrm{F}_{3,8}=1.68, \mathrm{p}=0.380\right)$. Final ammonia concentrations were not significantly different among temperature treatments $\left(\mathrm{X}_{(3)}^{2}=6.27, \mathrm{p}=0.10\right.$; Table 1$)$.

\section{Discussion}

After 21 days of temperature experimentation, eel weight was significantly greater than initial values, suggesting that rearing conditions in our laboratory were favorable for glass eel growth. Studies on the growth of juvenile eels do not always yield noticeable gains in weight so quickly. DeSilva, Gunasekera, Ingram and Dobson [35] found a decrease in the mean weight of Australian short fin 
glass eels (Anguilla australis) held at $\sim 23^{\circ} \mathrm{C}$ during an initial 28 days within the laboratory. However a significant increase in weight was observed during the final 28 - 42 days of experimentation. If there was an initial decrease in weight in our study, eel growth rebounded quickly except within the $14^{\circ} \mathrm{C}$ treatment. All treatments showed a positive increase in weight except the $14^{\circ} \mathrm{C}$ treatment where eels lost an average of $0.003 \mathrm{~g}$ ( $2 \%$ of their body mass).

The initial growth period for juvenile eels is typically characterized by a wide variation in growth rate [19]. In the present study, temperature appeared to increase the variation in growth. This increase may not have been a direct effect of temperature, but instead changes in social behavior at the varying temperatures. Barila and Stauffer [36] observed aggressive behavior in eels only at temperatures above $18^{\circ} \mathrm{C}$ (none observed at $6^{\circ} \mathrm{C}$ or $12^{\circ} \mathrm{C}$ ) with biting and gripping of the tail or head of individuals (resulting in infected wounds) occurring above $24^{\circ} \mathrm{C}$. It has also been found that aggressive behavior can affect the growth of eels with stressed individuals not consuming food [19].

Eel condition and temperature showed a positive relationship, although nonsignificant, with rising slope (b) values as acclimation temperature increased indicating faster growth in weight than in length for warmer temperatures [37]. The data combined from this study (low variation in the data, moderate mortality, higher body condition, and positive changes in length and weight) suggest that the $18^{\circ} \mathrm{C}$ and $22^{\circ} \mathrm{C}$ treatments produced the greatest growth and survival in the glass eels. Optimum temperatures in this range are lower than previously identified for the American eel. American eel elvers were reported to have optimal growth between $28^{\circ} \mathrm{C}$ and $29^{\circ} \mathrm{C}$ [31]; however, the eels used by Tzeng, Wang and Wang [31] were elvers, a later developmental stage compared to the glass eels used in the present study and collected from a warmer climate. While differences in optimal thermal conditions have been noted at different life stages within a single species [30], these differences between studies could also be due to geographic variation between collection sites (Central America versus Northeastern North America) [38]. Further investigation into how both of these factors (developmental stage and collection site) influence physiological optima warrant further investigation both from an aquaculture and climate change perspective. Additionally, extending the experimental period, beyond 21 days, may also increase the differences in growth among the temperature treatments. However, eels reared beyond 21 days are more likely to metamorphose to the next life stage (elvers) which was not the life stage of focus for this study.

Even though our results suggest an optimal temperature range of $18^{\circ} \mathrm{C}-22^{\circ} \mathrm{C}$ for glass eel growth and survival, there is no way to assess whether this temperature corresponds with a natural temperature preference (i.e. if eels in the wild actively seek habitat at or near this temperature). In a separate study, however, American eels collected from Tuckahoe Creek, MD, were acclimated to $6^{\circ} \mathrm{C}$, $12^{\circ} \mathrm{C}, 18^{\circ} \mathrm{C}, 24^{\circ} \mathrm{C}$, or $30^{\circ} \mathrm{C}$ and then tested for their temperature preference [36]. Regardless of acclimation temperature, all eels preferred $16.7^{\circ} \mathrm{C}$. Similar results 
have also been found in other species of glass eels. August and Hicks [39] surveyed glass eel populations in a New Zealand river and found that longfin ( $A$. dieffenbachia) and shortfin (A. australis) migrating glass eels had a preference for water temperatures between $12^{\circ} \mathrm{C}$ and $20^{\circ} \mathrm{C}$, with a clear optimum of $16.5^{\circ} \mathrm{C}$. Future studies investigating how our laboratory observations translate to habitat selection in the field would be useful for identifying optimal stocking conditions and locations.

Somewhat unexpectedly, gas bubbles became evident on the anterior portion of eels after 6 days of experimentation. Gas bubble disease results from exposure to water supersaturated with atmospheric gases and is often prevalent in hatcheries supplying well water to fish or in the wild below dams [40]. Fish suffering from this disease can have visible bubbles near their eyes or under their skin, hemorrhages, emboli in the blood vessels, and exhibit abnormal behavior and eventually death (i.e. loss of equilibrium or writhing) [41]. The number of experimental buckets containing eels with gas bubbles did not differ from chance; however, none were observed in the $14^{\circ} \mathrm{C}$ treatment and the maximum number of buckets with gas bubbles occurred under the warmest temperature treatment, likely due to the positive relationship between gas saturation and water temperature [41].

The specific effects of gas supersaturation on fish vary with ontogeny and according to fish species. Gas bubble disease is most often associated with excess levels of dissolved nitrogen in the water rather than high levels of dissolved oxygen or total dissolved gases, but extreme amounts of any dissolved gas can lead to negative effects [41]. Total gas pressure or $\Delta \mathrm{p}$ are the parameters that best characterize dissolved gas levels [42] [43]. In general, potentially harmful levels of nitrogen saturation for fish occur at or above $110 \%$ and $2-3$ times these levels for dissolved oxygen [41]. Dissolved nitrogen levels of $118 \%$ to $125 \%$ have been specifically reported to cause negative effects in adult American eels and Japanese eels ( $A$. japonica) [41]. Information on negative levels of dissolved gases for juvenile eels (glass eels and elvers) is absent, but negative effects have been observed in other larval fish at $\sim 106 \%$ total gas saturation for steelhead trout ( Salmo gairdneri), Chinook salmon (Oncorhynchus tshawytscha), and lake trout (Salvelinus namaycush) [44] [45] [46] and $\Delta \mathrm{p}$ values ranging from $10-20 \mathrm{~mm}$ $\mathrm{Hg}$ in cold water species [42]. Other fish species appear to be less sensitive to total gas saturation, with warm water species capable of tolerating $\Delta \mathrm{p}$ values between $30-40 \mathrm{~mm} \mathrm{Hg}$ [42]. Similarly, walleye fry (Stizostedium vitreum) can withstand total gas levels of $123 \%$ with no visible bubble formation and no effect on survival [47].

During our study, total nitrogen saturation remained well below the values reportedly toxic to adult eels, and oxygen saturation ranged between $131 \%$ and $164 \%$, again, below the levels harmful to most fish. Total gas pressure, on the other hand, ranged from $103 \%$ to $108 \%$, at or near levels that are reportedly harmful to larval trout [44] [45]. $\Delta \mathrm{p}$ values were also high and within or above 
the range reported to be critical for warm water species [42]. Further investigation is necessary to define critical dissolved gas limits for eels across life stages.

Perhaps related to gas saturation, we observed the greatest mortality at the highest temperature treatment. Other potential mechanisms could include direct mortality due to temperature, increased disease (fungus, parasites, bacteria, etc.) prevalence and transmission rates at warmer temperatures, or any combination of these factors. We also observed greater size variability at warmer temperatures, an observation that has been noted in other larval fish species [48]. This variation may have increased competitive interactions among individuals leading to increased mortality. Finally, ammonia build up can also inhibit growth and increase mortality. However, ammonia levels were extremely low in all of our treatments and in fact, the greatest concentration of ammonia occurred in the $14^{\circ} \mathrm{C}$ treatment $\left(0.016 \pm 0.004 \mathrm{mg} \cdot \mathrm{L}^{-1}\right)$. Previous studies have shown concentrations below $0.07 \mathrm{mg} \cdot \mathrm{L}^{-1}$ do not have an effect on survival or growth rate of other eel species [49] [50]; therefore it is unlikely that ammonia build-up or toxicity contributed to the experimental results. Further investigation into the relationship between mortality and temperature is warranted as it may have direct implications for eel health and survivorship at lower latitudes where water temperatures are regularly at or above $26^{\circ} \mathrm{C}$.

While $18^{\circ} \mathrm{C}-22^{\circ} \mathrm{C}$ temperatures resulted in overall greater growth and condition and less variation in size and mortality than the other treatments, these effects were only measured for a short duration and differences between treatments were observable, but often statistically insignificant. Nonetheless, this is one of the first studies on American glass eel rearing conditions and to our knowledge provides some of the first documentation of gas bubble disease in American glass eels. This study should provide a basis for future investigations into the thermal biology of this highly imperiled species.

\section{Acknowledgements}

The authors thank D. Spooner, W. Lellis, B. Watten, and J. Newhard for comments that greatly improved the quality of the manuscript. We would also like to thank J. Devers and S. Minkkinen of the US Fish and Wildlife Service, Maryland Department of Natural Resources, and the Tiadaghton Audubon Society for their aid in eel collection and transportation. All supporting data for this manuscript are available from the USGS Science Base repository at https://doi.org/10.5066/P9NXBU7C. The US Geological Survey Fisheries Program contributed to this work. Any use of trade, product, or firm names is for descriptive purposes only and does not imply endorsement by the US Government.

\section{Conflicts of Interest}

The authors declare no conflicts of interest regarding the publication of this paper. 


\section{References}

[1] Haro, A., Richkus, W., Whalen, K., Hoar, A., Busch, W.D., Lary, S., Brush, T. and Dixon, D. (2000) Population Decline of the American Eel: Implications for Research and Management. Fisheries, 25, 7-16. https://doi.org/10.1577/1548-8446(2000)025<0007:PDOTAE >2.0.CO;2

[2] Richkus, W.A. and Whalen, K. (2000) Evidence for a Decline in the Abundance of the American Eel, Anguilla rostrata (LeSueur), in North America since the Early 1980s. Dana, 12, 83-97.

[3] Atlantic States Marine Fisheries Commission (2000) Interstate Fishery Management Plan for American Eel (Anguilla rostrata). Fishery Management Report, No. 36.

[4] Watene, E.M. and Boubee, J.A.T. (2005) Selective Opening of Hydroelectric Dam Spillway Gates for Downstream Migrant Eels in New Zealand. Fisheries Management and Ecology, 12, 69-75. https://doi.org/10.1111/j.1365-2400.2004.00422.x

[5] Machut, L.S. and Limburg, K.E. (2008) Anguillicola crassus Infection in Anguilla rostrata from Small Tributaries of the Hudson River Watershed, New York, USA. Diseases of Aquatic Organisms, 79, 37-45. https://doi.org/10.3354/dao01901

[6] Hodson, P.V., Castonguay, M., Couillard, C.M., Desjardins, C., Pelletier, E. and McLeod, R. (1994) Spatial and Temporal Variations in Chemical Contamination of American Eels, Anguilla rostrata, Captured in the Estuary of the St. Lawrence River. Canadian Journal of Fisheries and Aquatic Sciences, 51, 464-478.

https://doi.org/10.1139/f94-049

[7] Labar, G.W. and Facey, D.E. (1983) Local Movements and Inshore Population Sizes of American Eels in Lake Champlain, Vermont. Transactions of the American Fisheries Society, 112, 111-116. https://doi.org/10.1577/1548-8659(1983)112<111:LMAIPS >2.0.CO;2

[8] Rupp, R.S. and Deroche, S.E. (1965) Standing Crops of Fishes in Three Small Lakes Compared with $\mathrm{C}^{14}$ Estimates of Net Primary Productivity. Transactions of the American Fisheries Society, 94, 9-25.

https://doi.org/10.1577/1548-8659(1965)94[9:SCOFIT]2.0.CO;2

[9] Ogden, J.C. (1970) Relative Abundance, Food Habits, and Age of the American Eel, Anguilla rostrata (LaSueur), in Certain New Jersey Streams. Transactions of the American Fisheries Society, 99, 54-59. https://doi.org/10.1577/1548-8659(1970)99<54:RAFHAA>2.0.CO;2

[10] Denoncourt, C.E. and Stauffer, J.R.J. (1993) Feeding Selectivity of the American Eel Anguilla rostrata (LeSueur) in the Upper Delaware River. American Midland Naturalist, 129, 301-308. https://doi.org/10.2307/2426511

[11] Willard, D.E. (1977) The Feeding Ecology and Behavior of Five Species of Herons in Southeastern New Jersey. The Condor, 79, 462-470. https://doi.org/10.2307/1367726

[12] Blackwell, B.F., Krohn, W.B. and Allen, R.B. (1995) Foods of Nestling Double-Crested Cormorants in Penobscot Bay, Maine, USA: Temproal and Spatial Comparisons. Colonial Waterbirds, 18, 199-208. https://doi.org/10.2307/1521481

[13] Smogor, R.A., Angermeier, P.L. and Gaylord, C.K. (1995) Distribution and Abundance of American Eels in Virginia Streams: Tests of Null Models across Spatial Scales. Transactions of the American Fisheries Society, 124, 789-803. https://doi.org/10.1577/1548-8659(1995)124<0789:DAAOAE >2.3.CO;2

[14] Lellis, W.A., White, B.S.J., Cole, J.C., Johnson, C.S., Devers, J.L., van Snik Gray, E. 
and Galbraith, H.S. (2013) Newly Documented Host Fishes for the Eastern Elliptio Mussel Elliptio complanata. Journal of Fish and Wildlife Management, 4, 75-85. https://doi.org/10.3996/102012-JFWM-094

[15] Krueger, W.H. and Oliveira, K. (1999) Evidence for Environmental Sex Determination in the American Eel, Anguilla rostrata. Environmental Biology of Fishes, 55, 381-389. https://doi.org/10.1023/A:1007575600789

[16] Jessop, B.M., Shiao, J.C., Iizuka, Y. and Tzeng, W.N. (2002) Migratory Behaviour and Habitat Use by American Eels Anguilla rostrata as Revealed by Otolith Microchemistry. Marine Ecology Progress Series, 233, 217-229. https://doi.org/10.3354/meps233217

[17] Colombo, G. and Grandidr, G. (1996) Histological Study of the Development and Sex Differentiation of the Gonad in the European Eel. Journal of Fish Biology, 48, 493-512. https://doi.org/10.1111/j.1095-8649.1996.tb01443.x

[18] Jessop, B.M. (1987) Migrating American Eels in Nova Scotia. Transactions of the American Fisheries Society, 116, 161-170. https://doi.org/10.1577/1548-8659(1987)116<161:MAEINS>2.0.CO;2

[19] Degani, G. and Gallagher, M.L. (1995) Growth and Nutrition of Eels. Laser Pages Publishing, Jerusalem.

[20] Oliveira, K. (1999) Life History Characteristics and Strategies of the American Eel, Anguilla rostrata. Canadian Journal of Fisheries and Aquatic Sciences, 56, 795-802. https://doi.org/10.1139/f99-001

[21] COSEWIC (2006) COSEWIC Assessment and Status Report on the American Eel Anguilla rostrata in Canada. Committee on the Status of Endangered Wildlife in Canada, Ottawa, 10-71.

http://www.sararegistry.gc.ca/document/default_e.cfm?documentID=2452

[22] Otwell, W.S. and Rickards, W.L. (1981/1982) Cultured and Wild American Eels, Anguilla rostrata: Fat Content and Fatty Acid Composition. Aquaculture, 26, 67-76. https://doi.org/10.1016/0044-8486(81)90110-1

[23] Tibbetts, S.M., Lall, S.P. and Anderson, D.M. (2000) Dietary Protein Requirement of Juvenile American Eel (Anguilla rostrata) Fed Practical Diets. Aquaculture, 186, 145-155. https://doi.org/10.1016/S0044-8486(99)00363-4

[24] Sadler, K. (1979) Effects of Temperature on the Growth and Survival of the European Eel, Anguilla anguilla L. Journal of Fish Biology, 15, 499-507. https://doi.org/10.1111/j.1095-8649.1979.tb03633.x

[25] Degani, G. (1986) Dietary Effects of Lipid Source, Lipid Level and Temperature on Growth of Glass Eel (Anguilla anguilla). Aquaculture, 56, 207-214. https://doi.org/10.1016/0044-8486(86)90336-4

[26] Kamstra, A. and Heinsbroek, L.T.N. (1991) Effects of Attractants on Start of Feeding of Glass Eel, Anguilla anguilla L. Aquaculture and Fisheries Management, 22, 47-56. https://doi.org/10.1111/j.1365-2109.1991.tb00494.x

[27] Appelbaum, S. and Herwitz, S. (1989) A Technique for Maintaining Water Quality in Fish Tanks Containing Eels and Fish Larvae. Aquaculture and Fisheries Management, 20, 107-110. https://doi.org/10.1111/j.1365-2109.1989.tb00446.x

[28] Heinsbroek, L.T.N. and Kamstra, A. (1990) Design and Performance of Water Recirculation Systems for Eel Culture. Aquacultural Engineering, 9, 187-207. https://doi.org/10.1016/0144-8609(90)90005-K

[29] Knosche, R. (1994) An Effective Biofilter Type for Eel Culture in Recirculating Sys- 
tems. Aquacultural Engineering, 13, 71-82.

https://doi.org/10.1016/0144-8609(94)90026-4

[30] Dosoretz, C. and Degani, G. (1987) Effect of Fat Rich Diet and Temperature on Growth and Body Composition of European Eels (Anguilla anguilla). Comparative Biochemistry and Physiology Part A: Physiology, 87, 733-736. https://doi.org/10.1016/0300-9629(87)90391-4

[31] Tzeng, W.-N., Wang, Y.-T. and Wang, C.-H. (1998) Optimal Growth Temperature of American Eel, Anguilla rostrata (Le Sueur). Journal of Fisheries Society of Taiwan, 25, 111-115.

[32] American Public Health Association (1996) Standard Methods for the Examination of Water and Wastewater. 18th Edition, American Public Health Association, American Water Works Association and Water Environment Federation, Washington DC.

[33] Froese, R. (2006) Cube Law, Condition Factor and Weight-Length Relationships: History, Meta-Analysis and Recommendations. Journal of Applied Ichthyology, 22, 241-253. https://doi.org/10.1111/j.1439-0426.2006.00805.x

[34] Carlander, K.D. (1969) Handbook of Freshwater Fishery Biology, Volume One; Life History Data on Freshwater Fishes of the United States and Canada, Exclusive of the Perciformes.

[35] DeSilva, S.S., Gunasekera, R.M., Ingram, B.A. and Dobson, J.L. (2001) Weaning of Australian Shortfin Glass Eels (Anguilla australis): A Comparison on the Effectiveness of Four Types of Fish Roe. Aquaculture, 195, 133-148.

https://doi.org/10.1016/S0044-8486(00)00548-2

[36] Barila, T.Y. and Stauffer, J.R. (1980) Temperature Behavioral Responses of the American Eel, Anguilla rostrata (Lesueur), from Maryland. Hydrobiologia, 74, 49-51. https://doi.org/10.1007/BF00009014

[37] Ovidio, M., Tarrago-Bès, F. and Matondo, B.N. (2015) Short-Term Responses of Glass Eels Transported from UK to Small Belgian Streams. International Journal of Limnology: Annales de Limnologie, 51, 219-226. https://doi.org/10.1051/limn/2015016

[38] Conover, D.O. and Present, T.M.C. (1990) Countergradient Variation in Growth Rate: Compensation for Length of the Growing Season among Atlantic Silversides from Different Latitudes. Oecologia, 83, 316-324. https://doi.org/10.1007/BF00317554

[39] August, S.M. and Hicks, B.J. (2008) Water Temperature and Upstream Migration of Glass Eels in New Zealand: Implications of Climate Change. Environmental Biology of Fishes, 81, 195-205. https://doi.org/10.1007/s10641-007-9191-Z

[40] MacDonald, J.R. and Hyatt, R.A. (1973) Supersaturation of Nitrogen in Water during Passage through Hydroelectric Turbines at Mactaquac Dam. Journal of Fisheries Research Board of Canada, 30, 1392-1394. https://doi.org/10.1139/f73-226

[41] Weitkamp, D.E. and Katz, M. (1980) A Review of Dissolved Gas Supersaturation Literature. Transactions of the American Fisheries Society, 109, 659-702. https://doi.org/10.1577/1548-8659(1980)109<659:ARODGS>2.0.CO;2

[42] Colt, J. (1991) Aquacultural Production Systems. Journal of Animal Science, 69, 4183-4192. https://doi.org/10.2527/1991.69104183x

[43] Colt, J. (1984) Computation of Dissolved Gas Concentrations in Water as Functions of Temperature, Salinity, and Pressure. American Fisheries Society, Special Publication, 1-154. 
[44] Dawley, E.M. and Ebel, W.J. (1975) Effects of Various Concentrations of Dissolved Atmospheric Gas on Juvenile Chinook Salmon and Steelhead Trout. Fishery Bulletin, 73, 787-796.

[45] Jensen, J.O.T. (1988) Combined Effects of Gas Supersaturation and Dissolved Oxygen Levels on Steelhead Trout (Salmo gairdneri) Eggs, Larvae, and Fry. Aquaculture, 68, 131-139. https://doi.org/10.1016/0044-8486(88)90236-0

[46] Krise, W.F. and Herman, R.L. (1989) Tolerance of Lake Trout, Salvelinus namaycush (Walbaum), Sac Fry to Dissolved Gas Supersaturation. Journal of Fish Diseases, 12, 269-273. https://doi.org/10.1111/j.1365-2761.1989.tb00312.x

[47] Kindschi, G.A. and MacConnell, E. (1989) Communications: Factors Influencing Early Mortality of Walleye Fry Reared Intensively. The Progressive Fish-Culturist, 51, 220-226. https://doi.org/10.1577/1548-8640(1989)051<0220:CFIEMO>2.3.CO;2

[48] Houde, E.D. (1989) Comparative Growth, Mortality, and Energetics of Marine Fish Larvae: Temperature and Implied Latitudinal Effects. Fishery Bulletin, 87, 471-495.

[49] Sadler, K. (1981) The Toxicity of Ammonia to the European Eel (Anguilla anguilla L.). Aquaculture, 26, 173-181. https://doi.org/10.1016/0044-8486(81)90121-6

[50] Knights, B. (1989) Effects of Ammonia Accumulation on Metabolic Rates and Growth of European Eel, Anguilla anguilla L., in Relation to Warmwater Aquaculture. Aquaculture and Fisheries Management, 20, 111-117. https://doi.org/10.1111/j.1365-2109.1989.tb00447.x 